$\begin{aligned} \text { Martina Vitáčková } & \text { In search of adventure: Ladislav } \\ \begin{aligned} \text { Martina Vitáčková is junior lecturer in } \\ \text { the Dutch Department of Palacký }\end{aligned} & \text { Mikeš Pařízek, a Czech in the } \\ \begin{array}{c}\text { University Olomouc, Czech Republic. } \\ \text { E-mail: Martina.Vitackova@ } @ \text { seznam.cz }\end{array} & \text { Congo }\end{aligned}$

In search of adventure: Ladislav Mikeš Pařízek, a Czech in the Congo

Ladislav Mikeš Pařizzk's books, articles and lectures had a large impact on the image of the Congo as it existed in communist Czechoslovakia from the 1940s till the 1970s, but this Czech traveller and writer has almost been forgotten. Through an analysis of his works and of reviews of these works published in newspapers of the 1950s, the nature of the African discourse as it was created in communist Eastern Europe, as well as the (mis)use of this discourse by the ruling party, is revealed. Special attention will be paid to the illustrations accompanying his books, articles and lectures. Key words: Czech literature, Belgian Congo, colonialism, communism, the Other, Ladislav Mikeš Pařizek.

\title{
Introduction
}

Ladislav Mikeš Pařizek was the most esteemed authority on the Congo, and Africa in general, in Czechoslovakia from the early 1940s till the end of 1970s. However, the aim of this essay is not only to introduce a forgotten adventurer, traveller, writer and journalist, but also to focus on the creation of an African discourse in communist Central Europe. Through an analysis of some of Pařizek's books on the Congo and of reviews of his books, I would like to point out how this discourse was (mis)used by the communist regime and at the same time how this discourse was (mis)understood by people living under this regime. Pařizek's books on the Congo were not of a high literary standard, but because of the great number printed and the simplicity of style, they had a large impact on people in communist Central Europe and also contributed to the creation of a particular image of the Congo. These books, together with Pařizek's articles and lectures, were often the only source of information on the Congo and had considerable influence on the general knowledge about this African country.

Ladislav Mikeš Pařízek was born on 19 November 1907 as the thirteenth child of a blacksmith in České Budějovice in South Bohemia, which then still was a part of the former Austrian-Hungarian Empire. The idea of travel adventures fascinated Pařízek even as a child. He discovered Africa for the first time on the bookshelves of the neighbouring apartment. He read everything he found that had something to do with the "Dark Continent" (Pařízek 1967: 49-52). At that time, Pařízek also learned 
about the existence of Belgian Congo through Henry Morton Stanley's book In Darkest Africa (1890) (Pařízek 1982: 10).

After unsuccessful studies at a business academy Pařizek left the country at the age of 17 and travelled to France. At first he lived in his sister's house in Paris but he soon ran out of money and became an ideal target for people recruiting young men for the French Foreign Legion. The major part of his service Pařizek spent in Northern Africa. He left the Legion after three years because of a serious injury sustained in Algeria and moved to Marseille. In 1927 Pařizek started to study journalism at the École libre des sciences politiques in Paris. From 1928 onwards he earned his money as a journalist and a writer, writing about his great interest - Africa.

The first journey Pařizek made as journalist in 1928 took him again to Northern Africa. He wrote reports, scientific articles, popular articles and even a travelogue in French. He became a member of the "French Society of the Friends of Equatorial Africa" - a society founded in 1926 with the aim of supporting Congolese nationalists (Pařízek 1967: 79). Those who sponsored his membership were Pařízek's friends, Claudius Mgeba, originally from Senegal, and the journalist, Maurice Lefebvre.

However, to Pařizek Northern Africa still was not the Africa he had read about. He felt strongly attracted to the forests of Equatorial Africa, to the Congo, where the maps said hic sunt leones. His dreams of this exotic Africa came true a year later, on 16 April 1929, when Pařízek first put his feet on the soil of Belgian Congo. This journey was partially funded by the Society of the Friends of Equatorial Africa and by the advances for articles Pařízek was supposed to write for the magazines Matin and Miroir du Monde (Pařízek 1967: 79). Pařizek also claimed to have signed a contract with the Belgian state to write down the distances between villages situated in an unmapped area he was supposed to visit during his journey (Pařízek 1967: 80).

Pařizek's first "real" African journey began in Dar es Salaam in the former Tanganyika. There he took a train to Ujiji and after crossing Lake Tanganyika, he hired a native guide called Kpveke-vo and started the journey through the Belgian Congo on foot. It took more than eight months before Pařizek and his guide finally reached the capital of Belgian Congo, Leopoldville. All the obstacles and difficulties encountered on this journey paradoxically only deepened Pařizek's passion for the continent. As the traveller said in many interviews, articles and books, his love for the continent was born then, when standing on a hill, overlooking the Kassai province of the Belgian Congo (compare Pařízek 1982: 12-13).

This first journey became the primary source of inspiration for most of his subsequent books. Pařizek reminisced regularly about his first encounter with the "real" Africa, not only in the 1940s, but also in works published many years later. His most successful novel, Ǩeka kouzelnikù (The Medicine-men River, 1956) and his autobiography Mécesty za dobrodružstvím (My journeys to adventure, 1967) are just two examples of this enduring passion. 
In 1930 Pařizek was enlisted in the Czechoslovak army. After this national service he returned to České Budějovice, where he tried his hand at a number of jobs. In the meantime he was writing continuously. Through writing about the exploitation of black people in colonial Africa he protested against the oppression of his own people by the Nazis during the Second World War (Pařízek 1967: 98).

After the Second World War, which he spent mostly in Prague, Pařizek returned to Africa. He headed, together with photographer Rudolf Šinkovec, for French Western Africa. Their journey started in Dakar in Senegal and continued via Guinea and Liberia to Bamako in the former French Sudan. During his Congo trip he paid attention mostly to the habits, traditional practices and stories of native people. This time Pařizek became interested in colonial issues, especially the economic and social effects of colonization. In his last book he comments on the change in his focus:

The new observations were striking and made a great impression on me. My further work reflected these observations. After fascism was conquered by the allied forces, Africa was slowly awakening from the long colonial decay. The convincing triumph of the people of the USSR, the first socialist country in the world, helped to awake the liberal-minded attitude of the black race. (Pařízek 1982: 19) ${ }^{1}$

This shift of interest is clearly visible in his books from the 1950s onwards, e.g. the travelogue Afrika pod maskami (Africa under masks, 1950) and the novels Africké svitání (African dawn, 1952) and Kraj dvoji oblohy (The country with two skies, 1953). Pařízek's interest in colonial issues is also revealed in his friendship with anti-colonial African activists such as Fodeba Keita, later Minister of Interior of the Republic of Guinea, or Gabriel d'Arboussier, later president of the Grand Council of French Western Africa, who also wrote a foreword to Pařízek's book Afrika se probouzi (Africa's awakening, 1953). ${ }^{2}$

The proclamation of independence by Guinea in 1958 became the inspiration for his third journey to Central Africa. Together with the cameraman, Lubomír Mikula, Pařizek reached Conakry on 1 May 1959. Witnessing the (communist) Labour Day celebrations in the newly independent country became, as he continuously emphasised in many interviews, articles and books, one of the most significant moments of his life (e.g. Pařízek 1982: 28). As he had done in 1948, Pařízek headed to Kandia and then to the settlement of Farranah. But from there he took a different route. He was deeply attracted to the holy mountain at the border with Sierra Leone where the source of the river Niger (Tembi) was assumed to be. However, when reaching that spot, he found only a dry hollow. On 21 May 1959 at 10.07 a.m. the Czechoslovak traveller, followed by the cameraman capturing his every step, "discovered" the real source of the river in the holy woods not far from the assumed source. This is how Pařízek described the moment in Mécesty za dobrodružstvím: 
Finally the densest bush was behind me. My feet were floundering in the moss growing in between the rocks. I was walking through places where, as generally believed, living people were offered to the gods and that, as the natives told me, had never been stained by the feet of a white man. Suddenly I stopped. Under the big rocks on my right side I saw a shimmering of water between the thick ferns. (Pařízek 1967: 191) ${ }^{3}$

Pařizek was then 51 years old. The discovery of the real source of the river was one of the high points both in his career as an adventurer and a traveller and in his personal life. Pařízek returned to Africa once again in 1975 as a member of a group of Czechoslovak communist journalists on a journey to Egypt and Tunisia (Pařízek 1982: 29).

\section{Pařízek's work}

As already mentioned, Pař́zek's journeys, and especially the first one, were the main inspiration for his writing. According to an interview in the Sunday magazine of the newspaper Práce (The Labour, 23 October 1971) Pařízek wrote 32 books, eleven of them intended for young readers. Together with the last book, his memoir Nejkrásnějšiživot (The most beautiful life, 1982) his oeuvre comprises 33 books of different genres. Apart from one book dedicated to his experiences in the Foreign Legion (Legie sebevrahù [Legion of self-murderers]) and a book about the May uprising in 1945 in Prague, all the books are strongly connected to Africa. However, even these other two books "are not absolutely free of memories of Africa" (Pařízek 1982: 24). Pařízek was also a co-author of many educational books, mostly for children and youth, about Africa. He published a number of travelogues using the knowledge and experience from his journeys and was the author of a number of books on African fairy and folk tales. Most of these books were often republished and also translated into Slovak, German, Hungarian and Polish.

Most of his books show "orientalistic" features, such as using a foreign language. Some of them even have their titles in one of the Congolese native languages as well (e.g. Mfumu nsargi [Prague, 1943] or Vo mo kpve [Prague, 1942]). But Pařízek was no typically Western "orientalist" since he was strongly critical of the colonial system.

Pařízek's oeuvre consists of novels, travelogues and literature for young readers. From the 1950s onwards, Pařizek focused mainly on the third category, fully complying with the rules of socialistic realism:

The basis is a thrilling plot; however it should not be the only content of the book. A book has to provide its young readers with a wholesome and true picture of the surroundings in which the plot is situated. It should sketch the winsomeness of the landscape; truly depict the habits and character of the people and the influence of 
social changes in the struggle between the old and the new. In a good adventure book there is no place for superior and invulnerable supermen and other figments of the imagination. Of necessity, there has to be enough space for ethical considerations and a longing for a better future. (Pařízek 1982: 20-21) ${ }^{4}$

In the next paragraphs I would like to focus on two of Pařizek's books on the Congo to show in more detail how the author conveyed a specific image of that country (and actually the whole continent) to his readers. For this purpose I have chosen two different genres - a travelogue, Země našich snů (The country of our dreams, 1942) and an adventure novel for young readers, Hledači ztraceného stínu (The seekers of the lost shadow, 1943).

Země našich snů was published in 1942 with the subtitle $Z$ cest jižnim Konžskem (From journeys through the Southern Congo). It is obvious that "the country of our dreams" refers to the Congo. The plot is basically a chronological description of the journey Pařízek had made in 1929. The cover of the book shows a map of the African continent and a schematized drawing of an African woman standing in a river with palm trees on the riverbank. The book begins with a foreword by the author in which Africa is directly and theatrically addressed:

Africa, land of splendour and full of contrasts, fruitful and yet a virgin beauty of hot breath and fiery heart, I remember you through the rosary of years, never forgetting the day when you have, for the first time, held me in your arms. It was the most beautiful time of our love. I was then struggling with your pride and was begging for your mercy, trying to satisfy all your needs and desires, even at the cost of my own strength and health. You were a demanding mistress and yet there was nothing you could not have asked of me. (Pařízek 1942: 5)

In the foreword, which covers more than three pages, Africa is compared to a black female body that is conquered by Pařizek, a white man. The book itself continues exploring this colonial image. For example, Pařizek never neglects to inform the reader of the naked breasts of African women. He also stresses traditional practices and pays a lot of attention to polygamy and superstition, as well as to the African fauna and flora, not really differentiating between nature and the people living in it. There are a large number of photographs accompanying the text. At the end of the book maps of Africa and the Belgian Congo are provided, on which the journey the author made, is charted.

Pařizek depicts the Congo and its people to his European readers in a very colonial way as the Oriental Other, as he was expected to do by his reading public. However, he is at the same time very critical of the colonial system, especially of the behaviour of civil servants, of the colonial bureaucracy and of missionaries (Pařízek 1942: 118-21). Although Pařizek claims in his last book that in Země našich snủ he tried to 
introduce the complexity of the Congo to young readers, a very stereotypical image of Africa was presented (Pařízek 1982: 16).

Hledači ztraceného stínu (The seekers of the lost shadow), was published for the first time in 1943. It is a significant example of Pařizek's writing for young readers. The book tells a simple story of Jan, a white boy, and Zako, a black boy, trying to find the lost shadow, a symbol of unity and peace. At the beginning Zako has to leave his family and tribal village due to his disrespect of "tradition" (shown by the author in a very negative light as pure superstition). Zako sets out on a long journey to find the lost shadow, so that he can prove that the medicine-man was wrong. He is saved from death in the forest by a white family. On a symbolic level there is a critique of the superstition of black people, represented by the old medicine-man Kofa, which is contrasted with white civilisation, represented by Jan and his father.

The author himself comments on the creation of the book as follow: "A fortunate idea made me write Hledači ztraceného stínu [...] I have been working on this story with lots of concerns. Its symbolism - two boys of different skin colour are searching for justice and peace for the beleaguered country - was meant to be a protest against the circumstances of that time." (Pařízek 1982: 18)

The book received very positive reviews, especially for its high moral value. According to reviews in Czechoslovak newspapers the book should "not be absent from the bookcase of any children growing-up" (Hospodářské noviny, 05.06.1943). Another reviewer recommends Hledači ztraceného stínu to all boys under 10 years of age (Svět. Zlin, 22.04.1943). ${ }^{7}$

Paŕizek was also very active as journalist. He started writing in French in the 1920s and his first articles in the Czech language were published in the early 1930s after returning to his homeland. He cooperated with a wide range of magazines (Svobodné Československo (Free Czechoslovakia), Svět práce (The world of labour), Svět v obrazech (World in pictures), Lidé a země (Earth and people) and with various newspapers (Blümlová, Gilarová 2005: 6). Pařízek's articles visibly show, even more than his books do, his leftist political orientation. Pařízek joined the Communist Party long before the coup of 1948. His articles demonstrated an obvious political orientation even before a leftist political message became a prerequisite for publication. From the 1940s onwards Pařízek published many articles based on his African journeys with titles such as "Africké povídky" (African short stories), "Ze zápisníku cestovatele" (From the traveller's notebook), “Dnešní Afrika" (Today's Africa), "Černý kontinent" (The Black Continent), etc. The range of topics is extremely wide, e.g. an article for Lékařská revue (The Medical Review) about native medical practices and medicine-men in the Congo (Lékařská revue, 15.11.1939) or a linguistic study of native Bantu languages or politically oriented articles explaining the contemporary situation in the Congo.

In contrast to his books, Pařízek tends to be more willing to abandon the African theme in his articles. He writes about the state of agriculture in Czechoslovakia, inno- 
vations in manufacturing processes in one factory or another or workers accomplishing the "Five Year Plan" in two years, etc. He also often succeeded in combining African themes with contemporary political subjects, as can for example be seen in a pamphlet on the occasion of the third congress of collective farmers on 22 March 1957. ${ }^{8}$ In this pamphlet, "the politically correct" Czechoslovak writers wish farmers all the best. Pařízek writes: "Dear friends, let me tell something else as well. I dare say you might be interested in it. During my journeys through Africa, I had the occasion to come to know a lot about the life and work of the African small farmer or plantation worker. And believe me, it is unhappy work." (Zemědělské noviny, 22.03.1957) $)^{9}$

Another domain in which Pařizek disseminated knowledge about Africa and at the same time promoted communist thinking, were the lectures he held under the auspices of the Office for Further Education, a state office, which took care of disseminating knowledge among the population. Between 14 and 29 April 1961 Pařízek held 29 lectures for a total of 6684 listeners. In this period, just slightly more than two weeks, Pařizek spent 66 hours talking about Africa, more specifically the Congo. In the late 1950s and especially in the 1960s Pařízek was making 'tours' not only all over Czechoslovakia, but also in Poland and Hungary. He spoke in front of audiences ranging from factory workers to grammar school pupils or even soldiers and in different venues (factories, schools, restaurants, caserns, libraries or pioneers' clubhous$\mathrm{es}^{10}$ ), often holding more than one lecture a day and taking a free day only on Sundays. The impact Pařizek and his view on the Congo and Africa in general had on the knowledge of the people in Central European area must have been huge. This effect can for example be seen in numerous letters sent to Pařízek by his readers or attendees of his lectures. ${ }^{11}$

Pařízek, as a freelancer, kept a list of lectures he could offer and this serves as a very useful source of information about the different topics he discussed. He usually started by introducing Africa from a historical point of view, for example mentioning the overseas discoveries, the discovery and colonization of the Congo on behalf of the Belgian king Leopold II, the Berlin Conference in 1885, etc. The geographical part included topics the Czechoslovak public wanted to hear about, such as polygamy and superstition. Topics such as the export of Czechoslovak tractors to Guinea and the education system were also covered. Last but not least, the struggle of the African people for freedom was discussed with reference to Guinea and the Congo. Of course, Pařizek did not hesitate to mention the effective help of the USSR, CSSR "and other progressive countries" in freeing Africa. Pařízek was also prepared to adjust the content of the lecture to the needs and wishes of the public, which in actual fact meant the dictates of the ruling party. At the bottom of the list of lectures Pařizek pointed out that all the lectures carry a strong political content. ${ }^{12}$ 


\section{Main themes}

As Pařizek was in the first place a politically engaged writer and journalist, his writings had other than just recreational or aesthetical purposes. As already mentioned, his books were written in an uncomplicated style, accessible to the masses, using simple narrative structures. The key message emanating from his work is a critique of the colonial system and at the same time (especially in his works from the 1950s onwards) a hymn to communism.

In his books Pařízek combines two, at first sight completely different, political principles, namely anti-colonialism and communism. In the early 1940s Pařizek wrote about the exploitation of black people in Africa in order to point out the oppression of the Czechoslovak people by the Nazis.

The same principle was then used to support the communist ideology in his later writings. The Congolese were, regardless of the colour of their skin, people oppressed by western capitalists. Pařízek did not hesitate to compare the situation before the coup in Czechoslovakia in 1948 to the situation of the colonized people in the Belgian colony.

His appearance, however, contradicted his denunciations. Pařízek, dressed in white riding breeches and a white shirt showing his hairy chest, with white tropical helmet on his head, looked like a clone of Henry Morton Stanley. He often criticised the colonial practices of white men, especially Americans and Belgians. The colonizers in his books and articles are often portrayed as lumpy, bald, sweating and red from the sun (compare Pařízek 1942: 9, 15). In contrast to them, Pařízek seems to have almost no problems with the African climate. The writer claims to have an understanding of the "black race" but at the same time he represents the typically colonial attitude of knowing better than black people themselves what is good for them.

\section{Kpveke-vo and the others}

However, white colonizers or westerners in general were not the only characters in Pařizek's books that were used to support both the communist ideology and the anticolonial stance. The native guide hired by Pařizek appears in almost all of his books on the Congo. Kpveke-vo will later even become the main character in a book carrying his name (Kpveke-vo, 1953). As a result he became, in the minds of European readers, a symbol of the Congo.

The available information offers no means of finding out what Kpveke-vo himself thought about the relationship with the Czechoslovak adventurer. We can only rely on Pařizek's books. The writer is always very positive about his guide and often calls Kpveke-vo his friend. The uniqueness of the relationship between a young white man and an elderly black man is exemplified by the fact that he allowed Kpveke-vo to use familiar singular pronouns when speaking to him in French. However, at the 
same time Pařizek apparently had no problem with using "his friend" to carry his luggage and do other menial tasks.

Pařízek openly conveys his respect and admiration for Kpveke-vo, whom he calls by his Christian name Lucas, in his books and articles: "The more I was travelling with Lucas, the more I looked up to him. He was a language expert and an authority on native practices, philosopher, great hunter, courageous man and an African poet with a great sense of humour." (Pařízek 1967: 81) ${ }^{13}$

Pařizek expresses his admiration for the physical appearance and abilities of his native guide as well. Often he is even put higher than the colonial civil servants, who are depicted as less intelligent than Kpveke-vo. But the writer also repeatedly mentions the unmanageable sexuality of the black man (Pařízek 1942: 88, 255, 262; 1956: 44 45 ) and other stereotypical features and beliefs. The author describes Kpveke-vo as educated and wild at the same time; he had deliberately left civilisation in order to listen to his ancestors' voices. The portrayal of Kpveke-vo shows many characteristics of the Orientalist Other.

\section{Illustrations}

The effect Pařízek's "missionary work" had on spreading information about the Congo was in a great measure supported by illustrations, not only in his books, but also in his articles and on the posters for his lectures. Pař́zek's archive in the Památník Národního Písemnictví (Czech Museum of Literature) contains hundreds of examples of these posters.

The illustrations accompanying Pařizek's writings were often stereotypical images of exotic Africa. The image of an African woman with naked breasts and palm trees in the background is the one most frequently used in illustrations accompanying articles in newspapers and magazines. These illustrations are often not connected to the content of the article.

The deliberate effort to enhance the exoticism of his writings is made clear in a letter dated 28 September 1971, in which the famous Czech academic painter Zdeněk Burian asked Pařizek whether he could borrow some photographs to illustrate an article about Czechoslovak travellers in Africa. In a post scriptum the painter specifies, "Of course, I mean romantic photographs, not the civil ones, from your stay in the Congo." ${ }^{14}$

\section{Reviews}

Reviewers often praised Pařizek's literary work. However, it was not the literary quality they took to. For the purposes of this article, I have analyzed the word usage in 37 reviews from the 1940s and 1950s. The books are often called an "African novel" or a 
"negro novel" in the reviews. The reviewers accentuate the author's love of the "Dark Continent" and his knowledge of the psychology of both black and white. Most of the reviewers point out that these books are a very important and often the only source of information about Africa and the Congo. One reviewer even calls Pařízek's works an "appropriate enrichment of Czech culture" (Skládal 1943).

All the reviewers emphasize the mystical aspect of Africa, often mentioning the telegraph drums lokali and other stereotypical images of African culture that can be found in Pařizek's oeuvre. An analysis of word usage shows a large number of recurring words. The most frequent words are "exotic", "romantic" and "adventurous", which appear in almost every review (e.g. Elsner 1942, Skládal 1942, Soldán 1943).

\section{Conclusion}

What sort of image of the Belgian Congo and its people does L. M. Pařizek present to his readers and audiences and how was this image interpreted by the public?

By analysing some of Pařízek's works we can state that, although he wanted to offer an impartial report on the real situation in the Congo, he did not entirely succeed, primarily due to his inability to abandon thinking patterns that we would tend to call "western" or "colonial." Pařizek was passionate about the African continent and made a significant effort to spread information about Africa - especially about the Congo, which, in his eyes, still symbolised the "real" dark Africa. However, most likely as a result of his family's poor financial and social situation while he was a child, Pařízek supported communism. After communism became the official ideology in Czechoslovakia, the Communist Party turned the author and his work into a $\operatorname{cog}$ in its indoctrination machine. The illustrations that accompanied his books and articles acted as a manual for consumers on how to read his work.

As Pařízek stated in an interview for the Sunday magazine of Mladá Fronta (New front) on 28 May 1983: "Our people had, in many regards, a distorted view of Africa and its inhabitants and I hope that I, at least in some way, have managed to change these incorrect ideas." ${ }^{15}$ The question is whether he really succeeded.

\footnotetext{
Acknowledgments

I would like to thank the Památnik Národního Písemnictví (Czech Museum of Literature) and especially the field office at Staré Hrady and its staff, PhDr. Eva Bílková, Ivan Kouba and Mgr. Magdalena Šrůtová, who allowed me to work with the still uncatalogued Pařízek's archive. This is also where I got most of the materials I have used for this research. The archive contains mostly materials and documents collected by Pařízek himself, sometimes without any reference to the title or the date or origin of newspaper cuttings. In such cases I just refer to the "Pařizek archive", because it was not possible to find out from which newspaper the review was taken.
} 
1 I have translated all the citations from the original Czech purely for the purpose of this article. "Nové poznatky byly překvapující a silně na mne zapůsobily. Projevilo se to také v mé dalši práci. Po vítězství spojeneckých armád nad fašismem se Afrika začala probouzet z dlouhého útlumu koloniálního panství. Přesvědčivé vítězství lidu první socialistické země světa SSSR pomohlo probudit svobodomyslný postoj černého lidu." (Pařízek 1982: 19)

2 The Pařizek archive of the Památník Národniho Pisemnictvi also contains copious correspondence between the writer and political activists in French.

3 'Konečně jsem měl nejhustší splet' křovin za sebou. Nohy se mi bořily do mechu, který rostl mezi balvany. Kráčel jsem místy, na nichž podle všeobecné víry byly o výročních náboženských slavnostech konány lidské oběti a která podle tvrzení místních lidí ještě neposkvrnila noha bělocha. Náhle jsem se zastavil. Po pravé straně pod velikými balvany v hustých chomáčích kapradin se zaleskla voda." (Pařizek 1967: 191)

4 “Základem je napínavý děj. Nesmí však být jedinou náplní knihy. Ta má dávat mladým čtenářưm celkový a pravdivý obraz prostředí, ve kterém se děj odehrává. Musí líčit podmanivost krajiny, věrně zobrazovat zvyky a povahy lidí i působení společenských změn v boji mezi starým a novým. V dobré dobrodružné knize není místo pro nadřazené a nezranitelné supermany a přehnané výmysly. Bezpodmínečně v ní musí být dostatek místa pro etickou stránku a touhu po lepším zítřku." (Pařízek 1982: 2021)

5 “Afriko, země nádhery a kontrastů, plodná a přesto panenská krásko horkého dech a ohnivého srdce, vzpomínám na tebe růžencem let, aniž jsem zapomněl na den, kdy po prvé jsi mne sevřela ve své náruči. Byla to nejkrásnější doba naší lásky, když jsem zápolil s tvou hrdostí a kdy jsem prosil o slitování, snaže se vyhověti tvým potřebám i choutkám za cenu vlastních sil a ztráty svého zdraví. Byla jsi náročnou milenkou a nebylo nic, čeho bys nemohla na mněžádat." (Pařizek 1942: 5)

6 “Št’astná myšlenka mě dovedla k napsání knihy Hledači ztraceného stínu. [...]najejím prŕběhu jsem pracoval s velikým zaujetím. Jeho symbolika dva chlapci rozdílné pleti hledají spravedlnost a mír pro sužovanou zemi byla protestem k událostem tehdejší doby." (Pařízek 1982: 18)

7 The Pařizek archive contains a great number of reviews of Pařizek's books, especially from the 1940s and $1950 \mathrm{~s}$, collected by the author. These are mostly newspaper cuttings, leaving out the possibility to find out from which newspaper or magazine the review comes from.

8 Jednotné zemédělské Družstvo (JZD) or collective farms were the Czechoslovak variants on the Soviet kolchozy.

9 "Vážení prátelé, dovolte mi, abych vám řekl ještě něco jiného. Snad vás to bude zajímat. Na svých cestách Afrikou jsem měl př́ležitost poznat I život a práci drobného afrického zemědělce nebo plantážního dělníka. A věřte mi, že je to práce neradostná." (Pařízek 1957)

10 Pionýr (Pioneer) was a communist organisation that can be compared to the Boy Scouts. One of the main objectives of the organisation was the indoctrination of children with the official ideology.

11 Pařizek's correspondence can be found in the Pařizek archive of the Czech Museum of Literature.

12 According to a list of lectures held in the Prievidza region (now in Slovakia) from 1220 June 1961 Pařizek held three lectures on Wednesday, 14 June: at 8.00 a.m. for 565 listeners, at $11.00 \mathrm{a} . \mathrm{m}$. for 520 listeners and at 2.00 p.m. for 55 listeners; on Thursday, 15 June at $9.00 \mathrm{a} . \mathrm{m}$. he had 450 listeners, 320 listeners at 11.00 a.m. and 149 listeners at 4.00 p.m. The Pařizek archive of the Czech Museum of Literature also includes many labour contracts made between Pařzzek and the Office for Further Education for different periods, obliging Pařizek to a certain number of lectures in different parts of Czechoslovakia. See the list of lectures $O b s a h$ Přednášek cestovatele a spisovatele L. M.Pařizka z Prahy.

13 "Čím déle jsem s Lukášem Ziou putoval, tím víc jsem se mu obdivoval. Byl znalcem jazyků a zvyků lidu, filosofem, výtečným lovcem, statečným člověkem a byl básnikem Afriky se smyslem pro humor." (Pařizek 1967:81)

14 "Mám samozřjejmě na mysli fotografie romantické, ne civilní, z vašeho pobytu v Kongu." (Burian 1971)

15 "Naši lidé měli v mnoha ohledech na Afriku a její obyvatele zkreslený názor a věř́m, že se mi alespoň v něčem podařilo ty chybné pohledy poopravit." (Kopic, Neff, Pacner 1983) 


\section{Works cited}

[Anonymous]. 1943a. Týdně jednu knihu. [Review of Hledači ztraceného stínu.] Svět. Zlín. 22.04.1943. Prague: Czech Museum of Literature (Pařizek archive).

[Anonymous]. 1943b. Kulturní svět. [Review of Hledači ztraceného stínu.] Hospodářské noviny. 05.06.1943. Prague: Czech Museum of Literature (Pařżzek archive)

Blümlová, Dagmar; Gilarová, Zuzana (eds.). 2005. České Budějovice v paměti Ladislava Mikeše Pařízka (České Budějovice in memories of L. M. Pařizek). Pelhřimov: Nová tiskárna.

Burian, Zdeněk. 1971. Letter to L. M. Pařízek. Prague: 28.09.1971. Prague: Czech Museum of Literature (Pařízek archive)

Elsner, Luboš. 1942. Černý světadíl. Zteč. 11.12.1942. Prague: Czech Museum of Literature (Pařízek archive)

Glazarová, Jarmila; Říha, Bohumil; Pařízek, Ladislav Mikeš; Hečko, František; Toman, Josef; Tomanová, Miloslava; Kř̌̌ž, Ivan; Beneš, K. J.; Pleva, Josef V.; Otradovicová, J.; Drda, Jan; Kaplický, Václav; Káňa, Vašek. 1957. Slovo spisovatelů k III: sjezdu našich družstevniků. Zemědělské noviny, 22.03.1957.

Kopic, Jaroslav; Neff, Ondřej; Pacner, Karel. 1983. Z tátovy kovárny do posvátného háje. Víkend. Mladá fronta. 28.05.1983.

Lukeš, Klement; Pařízek, Ladislav Mikeš. 1961. PoznávámeAfriku. Bratislava: Osvetový ústav.

Martínek, Jiří. 1998. Kdo byl kdo. Naši cestovateléa geografové. Prague: Libri.

Pařizek, Ladislav Mikeš. 1939. Domorodí lékaři a kouzelníci v Kongu. Lékařská revue, 15.11.1939, 181-82.

1942. Zeměnašich snů. Prague: Česká grafická unie.

1950. Afrika pod maskami. Prague: Melantrich.

1952. Africké svitani. Prague: Melantrich.

1953. Afrika se probouzí. Prague: Orbis

1956. Belgické Kongo a jeho lid. Prague: MF.

1958. Černošské báje a pohádky. Prague: SNDK.

[1961]. Obsah Přednášek cestovatele a spisovatele L. M. Paříza z Prahy, KNT 4/5732/61. Prague: Czech Museum of Literature (Pařízek archive).

1967. Mé cesty za dobrodružstvím. České Budějovice: nakladatelství České Budějovice.

1969 [1943]. Hledačiztraceného stínu. Ostrava: Profil.

1982. Nejkrásnější život. Prague:Albatros.

Skládal, Antonín. 1942. Ukázka dobrodružného románu. Zájmy Povltaví. September 1942. Prague: Czech Museum of Literature (Pařizek archive).

1943. Afrika na obzoru. Zájmy Povltaví. 09.01.1943. Prague: Czech Museum of Literature (Pařízek archive).

Soldán, Fedor. 1943. Zajímavá reportáž z Afriky. České slovo. 23.04.1943. Prague: Czech Museum of Literature (Pařízek archive) 